\title{
RELIABILITY ASSESSMENT OF A COASTAL DIKE AND DUNE SYSTEM AT THE SOUTH OF FALSTER, DENMARK
}

\author{
Andreas Kortenhaus ${ }^{1}$, David Schürenkamp ${ }^{1}$, Thorsten Piontkowitz ${ }^{2}$, Hocine Oumeraci ${ }^{1}$
}

The 'Falster dike' is a system of a coastal vegetated dunes with a grass-covered sand dike protecting a low-lying area of about 7,000 summer houses, many of which being inhabited during winter, and therefore in danger of any storm surge induced flooding. The paper discusses (i) the assessment and uncertainties of relevant data such as bathymetry, topography, wind and wave data, water levels; (ii) deterministic calculations of wave run-up and overtopping of the dike without dunes; (iii) the calculations of dune erosion; and (iv) a reliability assessment of a dune and dike system. Results suggest that the dunes in front of the dikes lead to a significantly increased safety of the flood defences and will therefore withstand present and future conditions, including climate change scenarios.

Keywords: sea dike, dune, reliability assessment; safety of flood defences, wave overtopping, dune erosion

\section{INTRODUCTION}

Many existing coastal defence systems have been improved over the past and historically developed from experiences with major storm surges. Very often multi-purpose use of defences such as touristic aspects in providing a sand beach, including its access, cycling and walking paths close to the sea, even building activities behind or even in defence lines, and many further demands have triggered adaptations to coastal defences which need to be accounted for in any future assessments of defence safety.

In addition, uncertain developments such as climate change and sea level rise poses a demand on assessing the present and future safety of the aforementioned coastal defence systems. The 'Falster Dike' is a system of coastal vegetated dunes with a grass-covered sand dike (Figure 1) protecting a low-lying area of about 7,000 summer houses, many of which being inhabited during winter, and therefore in danger of any storm surge induced flooding. Access to the beach in front of the dune and a path on top of the dike are examples of touristic use of the defence system.

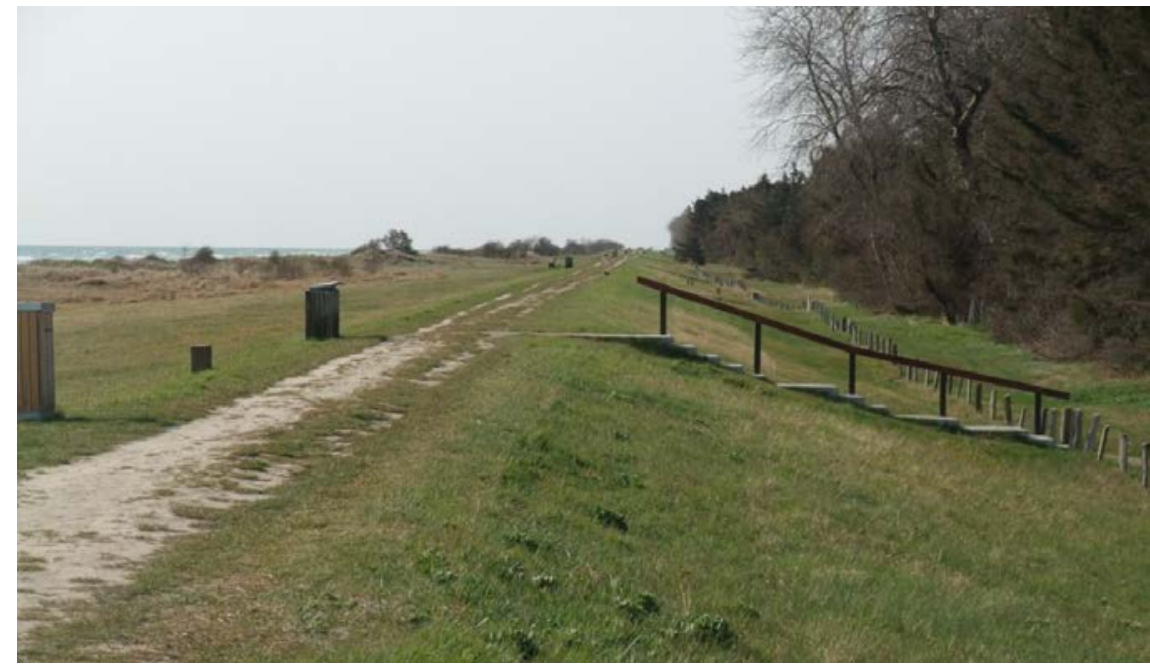

Figure 1. View of the vegetated dune system with a grass dike

Previous work on reliability assessments of coastal defences has mainly focussed on single defences rather than systems. Therefore, the Falster Dike Board (FDB) has commissioned the Leichtweiß-Institute to perform a safety assessment of the Falster Dike. The main objective is to assess the reliability of the Falster Dike, which includes (i) the probability of failure of the most critical dike and dune sections and (ii) suggestions of possible countermeasures, based on the results under (i).

Hence, the present case study focuses on the following key aspects: (i) assessment and uncertainties of relevant data such as bathymetry, topography, wind and wave data, and water levels; (ii) deterministic calculations of wave run-up and overtopping of the dike; (iii) calculations of dune erosion; and (iv) reliability assessment of a dune and dike system.

$1 \quad$ Leichtweiß-Institute for Hydraulic Engineering and Water Resources, Department of Hydromechanics and Coastal Engineering, Technische Universität Braunschweig, Beethovenstraße 51a, 38108 Braunschweig, Germany; contact author: a.kortenhaus@tu-bs.de

2 Danish Coastal Authority, Lemvig, Denmark, Tel.: +45 996363 24, Fax: +45 996363 99, Email: tpi@kyst.dk 
DATA ASSESSMENT

The dike stretch is $17 \mathrm{~km}$ long, reaching from the Gedser spit in the south to Elkenore beach in the north of the town of Marielyst. The dike mainly follows a north-south orientation and is slightly curved to the east in the northern part of the dike (Figure 2). A sandy dune with different types of vegetation is found in front of the sand dike which is grass covered with a path on top of it. The dune is characterised by different elevations and widths, from about $100 \mathrm{~m}$ in the south of the Falster Dike to only two or three tens of meters in the very north of the dike.

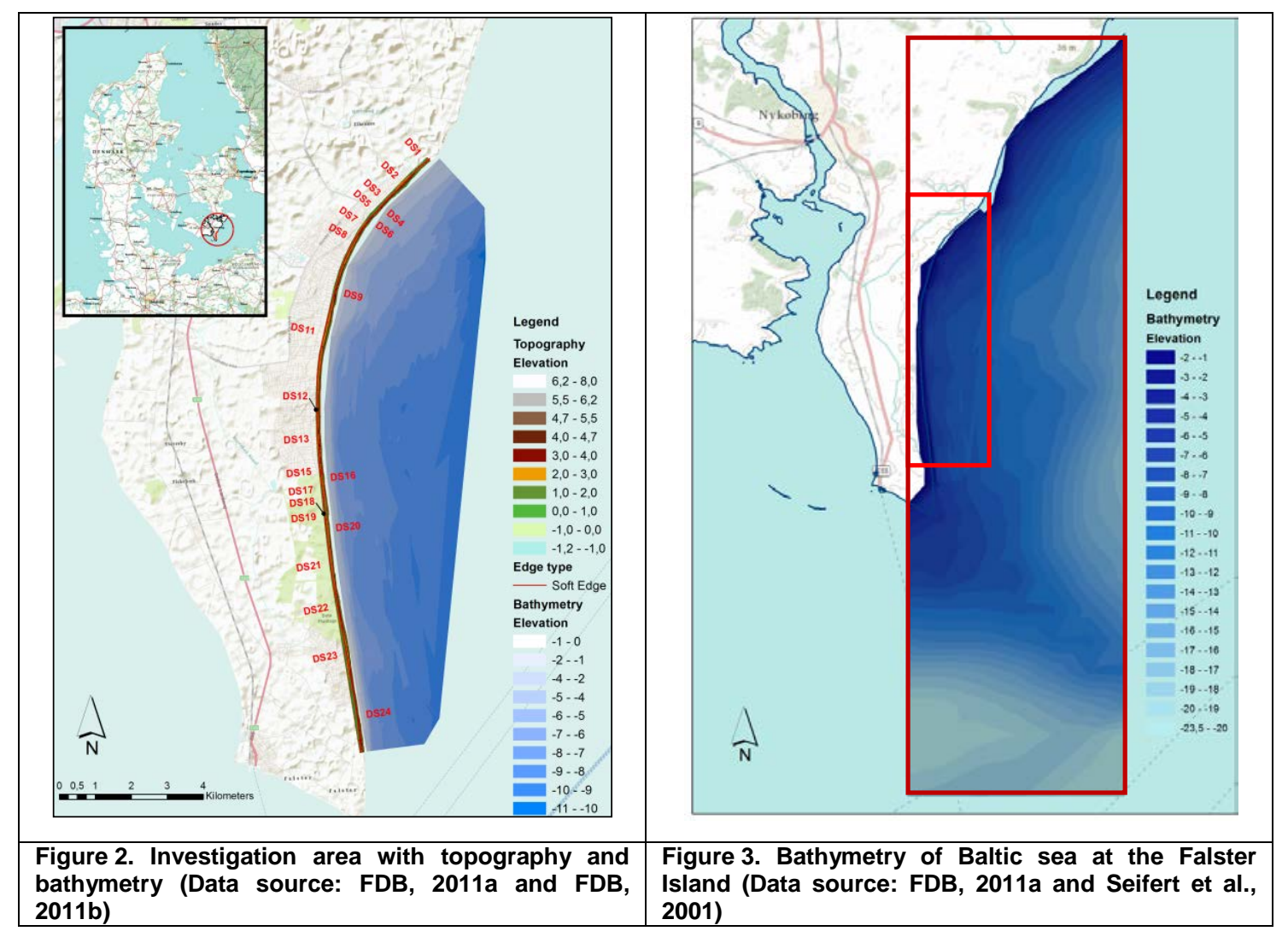

Similar sections of the dike were identified using the crest height and the average dike slope so that the dike could be split into 24 sections which are all of different lengths but being considered homogeneous in itself.

\section{Topography and Bathymetry}

The Danish Coastal Authority's (DCA) survey department performed a bathymetric profile survey of the near shore area along the Falster Dike (FDB, 2011a). The survey covers the sea floor from the beach to the depth contour line of -8m DVR90 (Danish Vertical Reference) and 17 profiles spacing $1.000 \mathrm{~m}$ have been surveyed. It was extended by data from the Leibniz Institute for Baltic Sea Research Warnemünde, IOW (Seifert et al., 2001).

Amongst others, these data were used to calculate the development of sea states, to simulate beach and dune erosion, and to determine wave run-up and mean wave overtopping rates. The bathymetry map of Falster is shown in Figure 3 with an interpolated resolution of $500 \mathrm{~m}$ for the coarse grid and 100 $\mathrm{m}$ of the nested fine grid.

A Digital Terrain Model (DTM) from 2007 with a horizontal resolution of $1.6 \mathrm{~m}$ is available and able to properly capture the dike and dune heights. The accuracy in elevation is specified by a root mean square error (RMSE) of $5.9 \mathrm{~cm}$ and a standard deviation of $3.44 \mathrm{~cm}$. Elevation data of the hinterland of the dike are also available. These topography data was provided by the Falster Dike Board (FDB, 2011b) and were processed with a geographic information system to examine the following dike and dune characteristics: 
- dike orientation (wave attack angle),

- dike height (see Figure 4 for details),

- seaward and shoreward dike slope,

- dune sand volume.

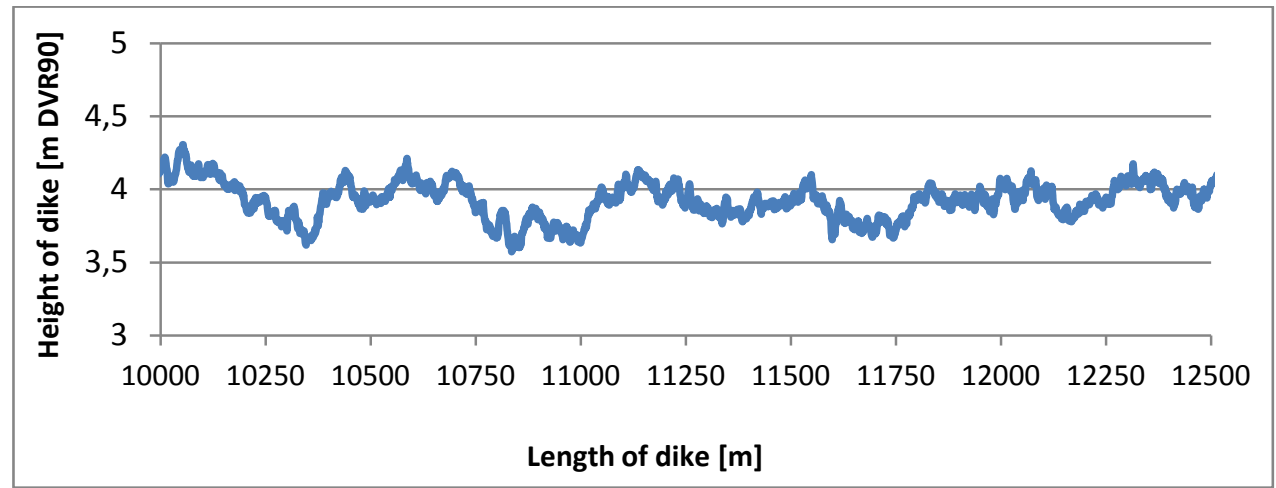

Figure 4. Dike height variation of the Falster dike for a dike stretch of 2,500 m

Figure 4 indicates variations of up to $80 \mathrm{~cm}$ in dike heights which are very relevant for any wave overtopping calculation. These variations and uncertainties in dike height estimations will be accounted for.

As mentioned before, the Falster Dike was divided alongshore into 24 dike sections from DS1 to DS24. The dunes were categorized in three main dune sections from DI to DIII using the key criteria such as 'dune height', 'dune capacity', and 'distance between dunes and dike crest'. The dune profile at the south end of the Falster dike (no dike) and the dune and dike crossing no. 5 in Marielyst were additionally analysed since they were believed to be the most critical cross profiles.

\section{Hydraulic Boundary Conditions}

One of the most important parameters influencing the safety of the coastal protection system is the water level (Table 1). Four different water levels with two different return periods and two different sea level rise (SLR) scenarios were taken into account. The sea level rise was considered to amount $30 \mathrm{~cm}$ for a period until 2055-2065 and $100 \mathrm{~cm}$ for a period until 2090-2100. The return periods were determined by statistical analysis of the water level of the gauges at Heasnes and Gedser (DCA, 2007).

Table 1. Water level scenarios

\begin{tabular}{|c|c|c|l|}
\hline & Water level & Return period & \multicolumn{1}{c|}{ Sea level rise (SLR) } \\
\hline Scenario & {$\left[\mathbf{m}^{\mathbf{1}}\right.$} & {$[\mathbf{1} /$ years $]$} & \\
\hline $\mathbf{A}$ & 1.50 & $1 / 20$ & $\mathrm{hw}_{20}$ return period of $\mathbf{1} / \mathbf{2 0}$ \\
\hline $\mathbf{B}$ & 1.69 & $1 / 100$ & $\mathrm{hw}_{100}$ return period of $\mathbf{1} / \mathbf{1 0 0}$ \\
\hline $\mathbf{C}$ & 1.99 & $1 / 100+\mathrm{SLR}^{2)}$ & $\mathrm{hw}_{2065} \mathbf{1} / \mathbf{1 0 0}$ water level + 30 cm (SLR) \\
\hline $\mathbf{D}$ & 2.69 & $1 / 100+\mathrm{SLR}^{2)}$ & $\mathrm{hw}_{2100} \mathbf{1} / \mathbf{1 0 0}$ water level + 100 cm (SLR) \\
\hline
\end{tabular}

${ }^{15}$ based on the DVR90 reference level; ${ }^{2)}$ SLR = sea level rise

The storm surge in 1872 reached a maximum water level in a range of $2.8 \mathrm{~m}$ (Rasmussen et al., 1997; DHI, 2006) at the eastern coastline of Falster. Therefore, since scenario D considered a very similar water level, it was believed that scenario D also includes calculations for the 1872 storm surge.

In order to consider not only the peak water level during a storm in the Baltic Sea, a time history of water level during a storm was considered. Therefore, a scenario was chosen with a total duration of 12 hours and with a duration of the maximum water level of 3 hours. For this purpose, a linear increase and a linear decrease of the water levels within 4.5 hours were assumed (cf. Figure 5).

The time history of the water level was considered by the numerical dune erosion model to account for the temporal development of the beach and dune erosion. For the simulation of the sea state and for the calculation of wave run-up and overtopping rates, a constant peak water level was assumed, hence assuming a conservative approach. 
Wind data of the Danish Meteorology Institute (DMI, 2011) for the stations ,Gedser Havn` and ,Gedser Odde، were analysed to determine the wind conditions at the island of Falster. Therefore, the wind speed was examined together with the wind direction (Kaste, 2011). The analysis of the wind data (Figure 6) resulted in a maximum wind speed of $20.1 \mathrm{~m} / \mathrm{s}$ in the range of wind direction of

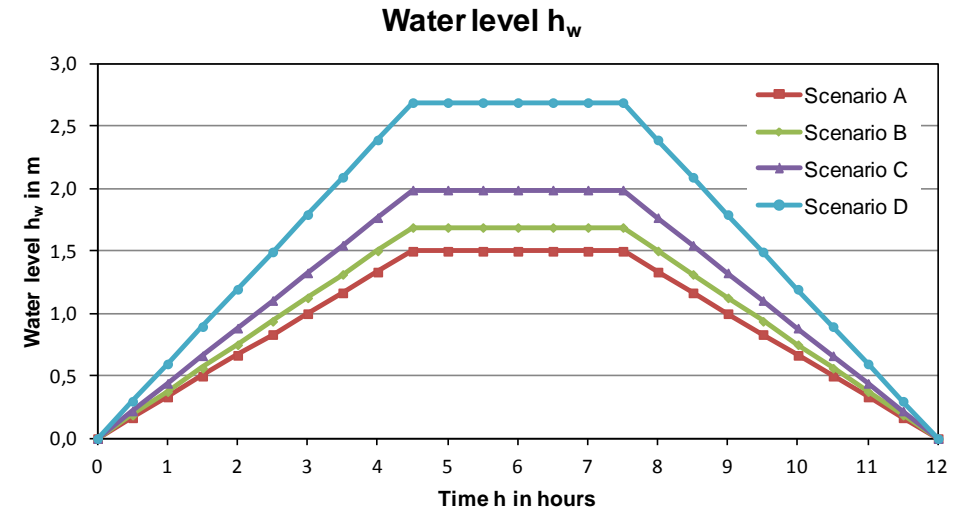

Figure 5. Development of water level hw of four storm surge scenarios $0^{\circ}$ (North) to $180^{\circ}$ (South). For the calculation of sea states, the maximum wind velocity was set to the direction of $90^{\circ}$ (East), again assuming the most conservative approach.

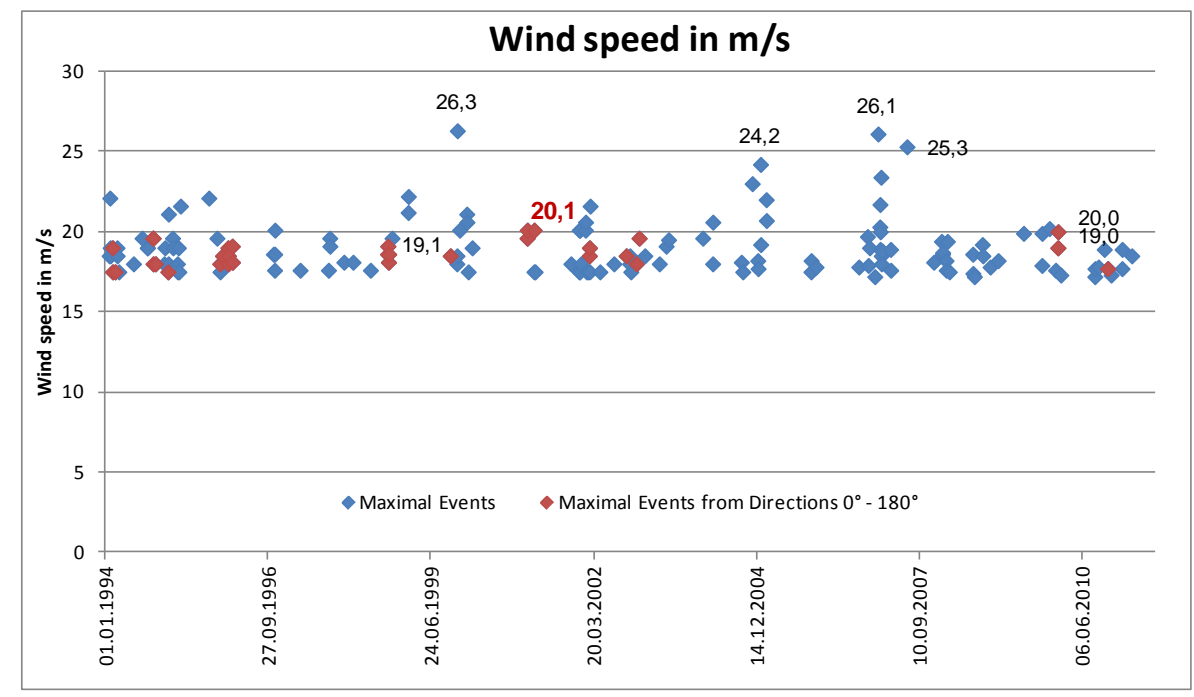

Figure 6. Maximum wind speed from directions $0^{\circ}-180^{\circ}$

The sea state was calculated from approximately $4 \mathrm{~km}$ offshore to the coastline. The following main parameters were computed:

- $\quad$ significant wave height $\mathrm{H}_{\text {sig, }}$

- $\quad$ peak wave period $\mathrm{T}_{\mathrm{p}}$,

- $\quad$ wave attack angle $\theta$.

For the analysis of the sea state in front of the coast of Falster, the numerical model 'SWAN' (Simulation WAves Nearshore, SWAN, 2006) was applied to simulate the local conditions. The results of this sea state model were used for the calculation of wave run-up, wave overtopping rates, and for the simulation of dune erosion. SWAN uses the spectral action balance equation to compute the evolution of wave growth. Terms of sources and sinks denote (SWAN, 2006):

- $\quad$ wave growth by the wind,

- $\quad$ nonlinear transfer of wave energy through three-wave and four-wave interactions,

- $\quad$ wave decay due to whitecapping,

- bottom friction,

- $\quad$ depth-induced wave breaking.

A JONSWAP-Spectrum was implemented as a boundary condition without any a priori restrictions of the spectrum. Therefore the significant wave height, the peak period and the wave direction at 
the outer boundary are needed as an input. Further initial conditions are wind speed and wind direction (SWAN, 2006). For 2D-computations equidistant grids were defined. Wahl (2007) determined the optimal cell size to be 50 to $100 \mathrm{~m}$. Therefore, a grid size of $100 \mathrm{~m}$ was chosen for the finer grid in front of the coastline. After the calculation of the sea state in a coarse grid, a finer grid next to the coastline is nested into the coarser model.

The sea state parameters in a water depth of $10 \mathrm{~m}$ were calculated (SPM, 1984 and EAK, 2002) using the available fetch lengths and wind speeds (for details see Kaste, 2011). These results are used as the boundary conditions for the numerical model. In Table 2 an overview of the SWAN boundary conditions for the coarse grid is shown.

Table 2. SWAN boundary conditions at offshore border

\begin{tabular}{|l|c|c|}
\hline Parameter & Unit & Value \\
\hline Wave height $\mathrm{H}_{\text {sig }}$ & $\mathrm{m}$ & 3.0 \\
\hline Wave period $\mathrm{T}_{\mathrm{p}}$ & $\mathrm{s}$ & 5.5 \\
\hline Wave angle $\theta$ & $\circ$ & 90 (East) \\
\hline Wind speed $\mathrm{U}$ & $\mathrm{m} / \mathrm{s}$ & 20.1 \\
\hline Wind direction & $\circ$ & 90 (East) \\
\hline
\end{tabular}

The calculation of dune and beach erosion was performed by the numerical model 'XBeach' ( $e \underline{X-}$ treme Beach behaviour, Roelvink et al., 2010). The XBeach model simulates the behaviour of sandy coasts with given hydrodynamic parameters (wave height, wave period, water level, wind, currents, wave-current interaction etc.) and morphodynamic parameters (grain size, sediment transportation, erosion process, etc.). The numerical model performs well for dune erosion, overwash and breaching and was therefore selected suitable for the assessment of the Falster Dike reliability (Streicher, 2012).

As one of the first models XBeach can calculate infragravity waves and wave group generated surf and swash motions which are found to be very important when it comes to dune erosion. Furthermore, XBeach provides an avalanching mechanism to simulate the slumping effects at the foredune during storm surge conditions (Roelvink et al., 2010). The computational simulation takes place in a 2DH environment. As input parameters an initial bathymetry and a grid system are defined. Hydrodynamic, morphodynamic and time parameters are set within the program. The main output is a timevarying bathymetry but also run-up levels and temporal change of hydrodynamic and morphodynamic parameters are simulated.

The numerical model XBeach was developed by Unesco IHE, the Delft University of Technology, and Deltares, The Netherlands. XBeach was tested in several case studies as well as in experiments. It has been found that the physics of dune erosion, overwash, breaching, avalanching, swash motion, infragravity waves, wave groups, wave current interaction, as to name a few, during extreme storm conditions are reliably implemented in the model (Roelvink et al., 2010).

The dune profile located south of the Falster Dike was calculated first as one of the probably critical cross sections. Therefore, the cross section of the dune and the bathymetry were prepared for the simulation of dune erosion. In addition, the dunes along the coastline were merged to three dune sections. The dune crossing no. 5 in Marielyst was separately assessed because of a very low dune capacity. In Table 3 five dune profiles are shown with dune sections, station marks, and the corresponding dike sections.

Table 3. Dune sections with stations marks

\begin{tabular}{|l|c|c|c|}
\hline Dune profile & Dune section & Station mark & Dike section \\
\hline North & D I & $0+000$ to $3+500$ & DS02 \\
\hline Marielyst & D II & $3+500$ to $9+500$ & DS13 \\
\hline Marielyst Crossing No. 5 & D II & $4+800$ & DS09 \\
\hline South & D III & $9+500$ to $17+600$ & DS18 \\
\hline South End & D III & $17+600$ & - \\
\hline
\end{tabular}




\section{METHODOLOGY}

The coastal protection system at the Falster Dike consists of a sand dike with natural dunes in front. During the performance of the safety assessment the dunes and dikes were separated and treated individually first and as a combined system later (Figure 7).

In a first step, the hydraulic boundary conditions were determined by water level statistics, wind parameters, topography and bathymetry. These parameters have been used to preliminarily determine the reliability of the Falster Dike by only taking into account the dike (and not the dune) and only considering wave overtopping simulations for four different water level scenarios (Kaste, 2011).

In the second step, the numerical model SWAN was applied to simulate the sea state in the nearshore area for the four water level scenarios as defined in Table 1. Deterministic and probabilistic approaches were then applied for the safety assessment of this protection system. Wave run-up and wave overtopping rates with regard to the local boundary conditions were determined. The wave run-up is measured vertically from the still water level. Wave overtopping describes the mean discharge of waves over the dike crest per meter width in $1 /(\mathrm{s} \cdot \mathrm{m})$. Two maximum admissible wave overtopping rates were selected as threshold values for the dike $(0.5 \mathrm{l} /(\mathrm{s} \cdot \mathrm{m})$ and 2.0 $1 /(s \cdot m))$.

For the analysis of wave run-up and wave overtopping rates, three different cases of the combined coastal protection system (Figure 7a) were determined:

- dunes without considering the dike (Figure 7b),

- dike without considering the dunes (Figure 7c),

- dike with a berm (combination of dike and dunes) (Figure 7d).

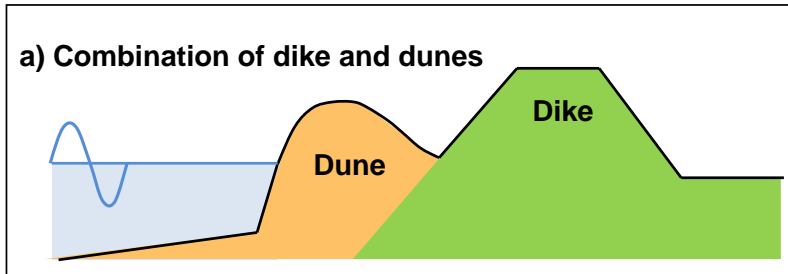

b) Dunes without dike

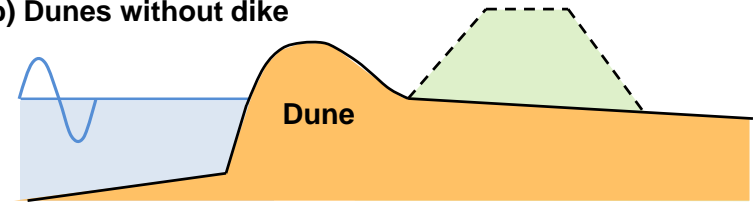

c) Dike without dunes

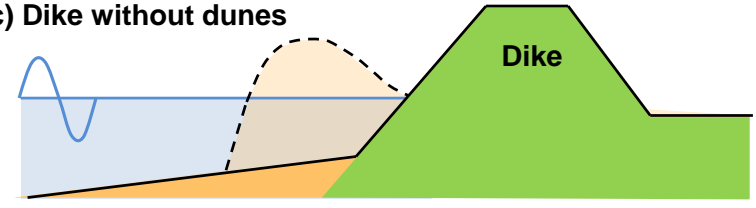

d) Dike with berm

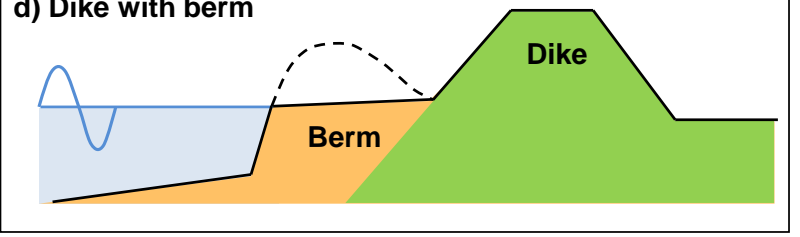

Figure 7. Classification of coastal protection system

Dunes without considering the dike: The dunes were separately assessed for the simulation of wave run-up, overwash and dune erosion. The beach and dune erosion was simulated by the numerical model XBeach. In order to minimize the simulation efforts, the dunes were divided into three dune sections DI, DII, and DIII.

Dike without considering the dunes: The dunes in front of the dike were neglected when calculating the wave run-up and wave overtopping rates for the dike. For each of the 24 dike sections the dike parameters were determined. Calculations of wave run-up and wave overtopping rates were performed according to the EurOtop Manual (EurOtop, 2007).

Combination of dikes and dunes: An updated dike geometry with a berm was applied for calculating wave run-up and wave overtopping rates (Figure 7d). The dike geometry was estimated from erosion simulations using XBeach and was simplified to a berm profile. This profile was assumed to no further erosion and could therefore be used for wave run-up and overtopping simulations.

In a further step, the combined coastal protection system was assessed by a probabilistic approach. The failure probabilities were calculated by Monte-Carlo simulations using the software tool Palisade@Risk. 
RESULTS

\section{Sea State Simulation with SWAN}

For the calculation of the sea state at the coastline and offshore, the numerical model SWAN was applied. A fine and a coarse grid were interpolated from depth profiles. The characteristics of these grids are shown in Table 4.

Table 4. Characteristics of the SWAN model grids

\begin{tabular}{|c|c|c|c|c|}
\hline Description & Origin $(U T M 32 U)^{1)}$ & Cell count & Cell size & $\begin{array}{l}\text { Width, } \\
\text { Height }\end{array}$ \\
\hline & {$[\mathbf{m}]$} & {$[-]$} & [m] & {$[\mathbf{m}]$} \\
\hline \multirow{2}{*}{$\begin{array}{l}\text { Coarse grid of the Baltic } \\
\text { Sea determined by Seifert et } \\
\text { al., } 2001\end{array}$} & $X_{0}=690985$ & \multirow[t]{2}{*}{$25 \cdot 94$} & \multirow[t]{2}{*}{500} & \multirow{2}{*}{$\begin{array}{l}12000 \\
47000\end{array}$} \\
\hline & $Y_{0}=6033167$ & & & \\
\hline \multirow{2}{*}{$\begin{array}{l}\text { Fine grid interpolated of } \\
\text { echo sounder profiles } \\
\text { (DCA) }\end{array}$} & $X_{0}=691046$ & \multirow[t]{2}{*}{$46 \cdot 163$} & \multirow[t]{2}{*}{100} & \multirow{2}{*}{$\begin{array}{l}4600, \\
16300\end{array}$} \\
\hline & $Y_{0}=6051928$ & & & \\
\hline
\end{tabular}

${ }^{1)}$ refers to the upper left corner of the grid with UTM 32U coordinates

For the simulation of the wave conditions in the nearshore area, the fine grid was nested into a coarse grid to consider the offshore wave conditions. The wind and wave boundary conditions were applied to the eastern model border of the coarse grid (about $12 \mathrm{~km}$ offshore). In these grids, the wave parameters (e.g. $\mathrm{H}_{\mathrm{s}}, \mathrm{T}_{\mathrm{p}}$ ) were calculated for each cell, and the output was prepared for a longshore line with $100 \mathrm{~m}$ distance to the coastline. These results were used for the calculation of wave run-up and wave overtopping rates. The sea state parameters at the offshore boundary of the fine grid were then used for the simulation of dune erosion. In Figure 8, the maximum wave height $\mathrm{H}_{\text {sig,max }}$ (determined as $\mathrm{H}_{\mathrm{m} 0}$ for XBeach) is shown for each dike section. The scenarios B and D are shown for a clear overview.

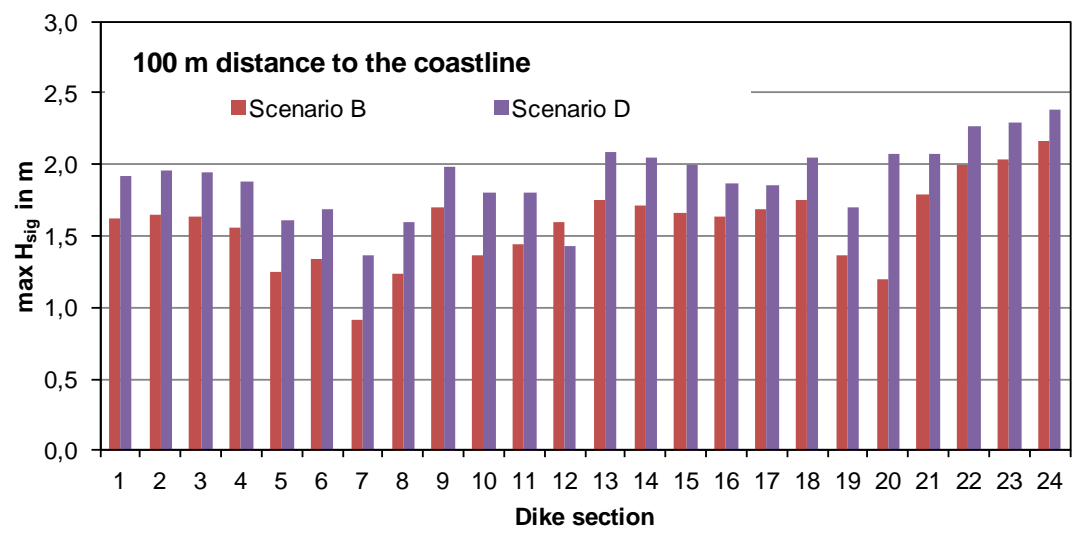

Figure 8. Wave height $\mathrm{H}_{\text {sig }}$ for each dike section in a distance of $100 \mathrm{~m}$ to the coastline

It can be seen from Figure 8 that the maximum significant wave height hardly exceeds $2.0 \mathrm{~m}$ at the shore which in most cases only occurs for Scenario D which is the highest water level $(2.69 \mathrm{~m}$ DVR). The low values in dike sections 7, 8, 19, and 20 result from a shallower bathymetry.

Figure 9 shows the wave period $\mathrm{T}_{\mathrm{m} 01}$ in a distance of $100 \mathrm{~m}$ to the coastline for each dike section. In comparison to the boundary condition of the wave period at a distance of ca. $11 \mathrm{~km}$ offshore $\left(\mathrm{T}_{\mathrm{m}-1,0}=5.5 \mathrm{~s}\right)$ a slightly lower wave period was calculated nearshore.

In sections 8 and 9, wave periods are larger than in the other dike sections due to the SWAN friction model. The bathymetry slope in the area of dike section 8 and 9 is shallower compared to the other sections. 


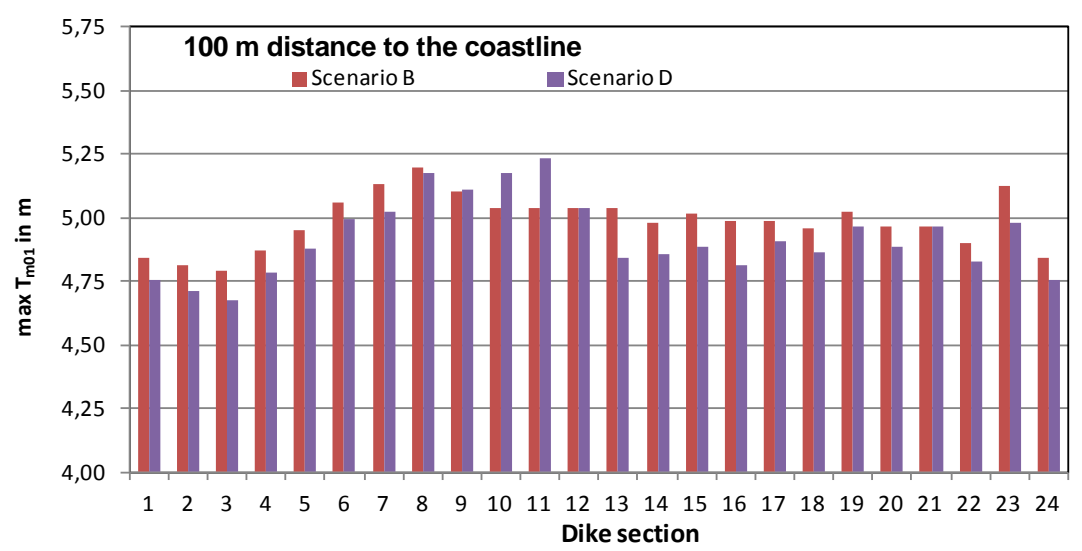

Figure 9. Wave period $\mathrm{T}_{\mathrm{m} 01}$ for each dike section in a distance of $100 \mathrm{~m}$ to the coastline

The wave attack angle, defined as the wave direction perpendicular to the coastline is provided in Figure 10. The dike sections are again given in ascending order from North to South.

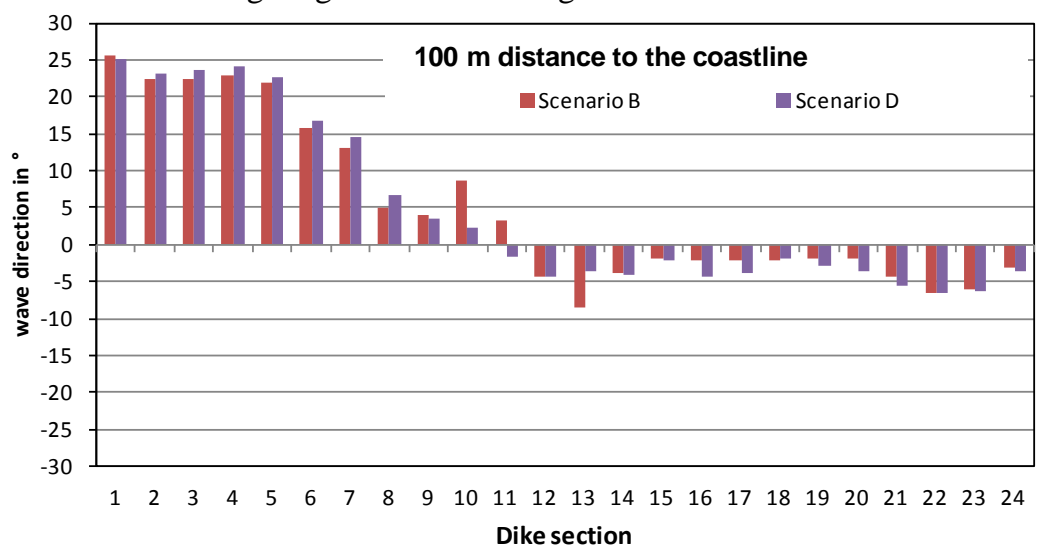

Figure 10. Mean wave direction $\theta$ for each dike section in a distance of $100 \mathrm{~m}$ to the coastline

In most cases (for dike sections 10 to 24), the wave attack is almost perpendicular to the coast whereas the northern part of the Falster Dike ranging from dike section 1 to 7 is mainly influenced by an oblique wave attack with a higher longshore component. It can be concluded, that in this case there exists a higher potential of sediment transport rates in longshore direction.

The sea state parameters were also extracted at the offshore boundaries (approximately $4 \mathrm{~km}$ offshore) for numerical simulation of dune erosion with the model XBeach. For application of the dune erosion model XBeach, a relation of wave height $\mathrm{H}_{\text {sig }}$ to water depth $d$ is used to calculate the temporal development of the wave height $\mathrm{H}_{\text {sig }}$ for each time step. In Figure 11, the example of wave heights $\mathrm{H}_{\text {sig }}$ at the offshore boundary of dune section D II (station mark 9+000) are shown for each water level scenario.

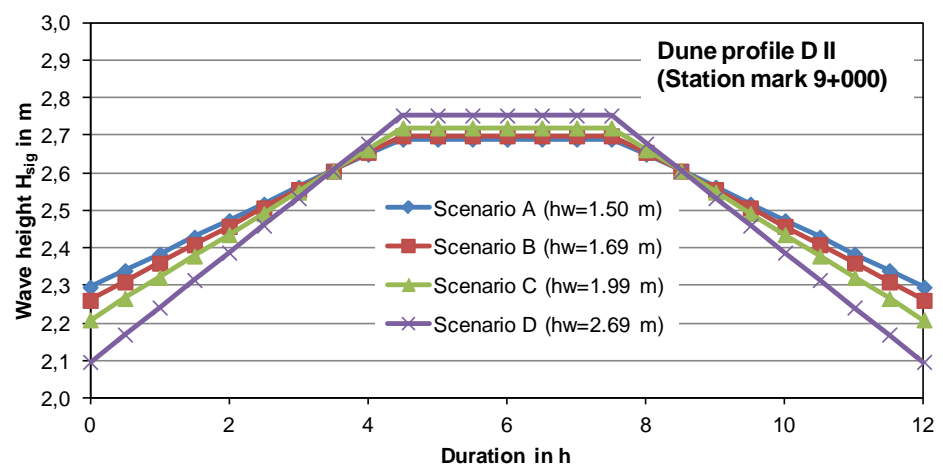

Figure 11. $H_{\text {sig }}$ at the model boundary of the cross profile $9+000$ 


\section{Simulation of Beach and Dune Erosion}

Numerical Model XBeach

The dunes were analysed without consideration of the dike (cf. Figure 7c). For the calculation of dune and beach erosion, wave run-up and overwash, the numerical model 'XBeach' was applied. The dunes along the coastline were merged to three dune sections with following marks: DI $0+000$ to $3+500$, DII $3+500$ to $9+000$, DIII $9+000$ to $17+600$. For each dune section, the particular worst case cross section was chosen in respect to dune volume and dune height (Figure 12, initial profile 1, 3, and 4, respectively).

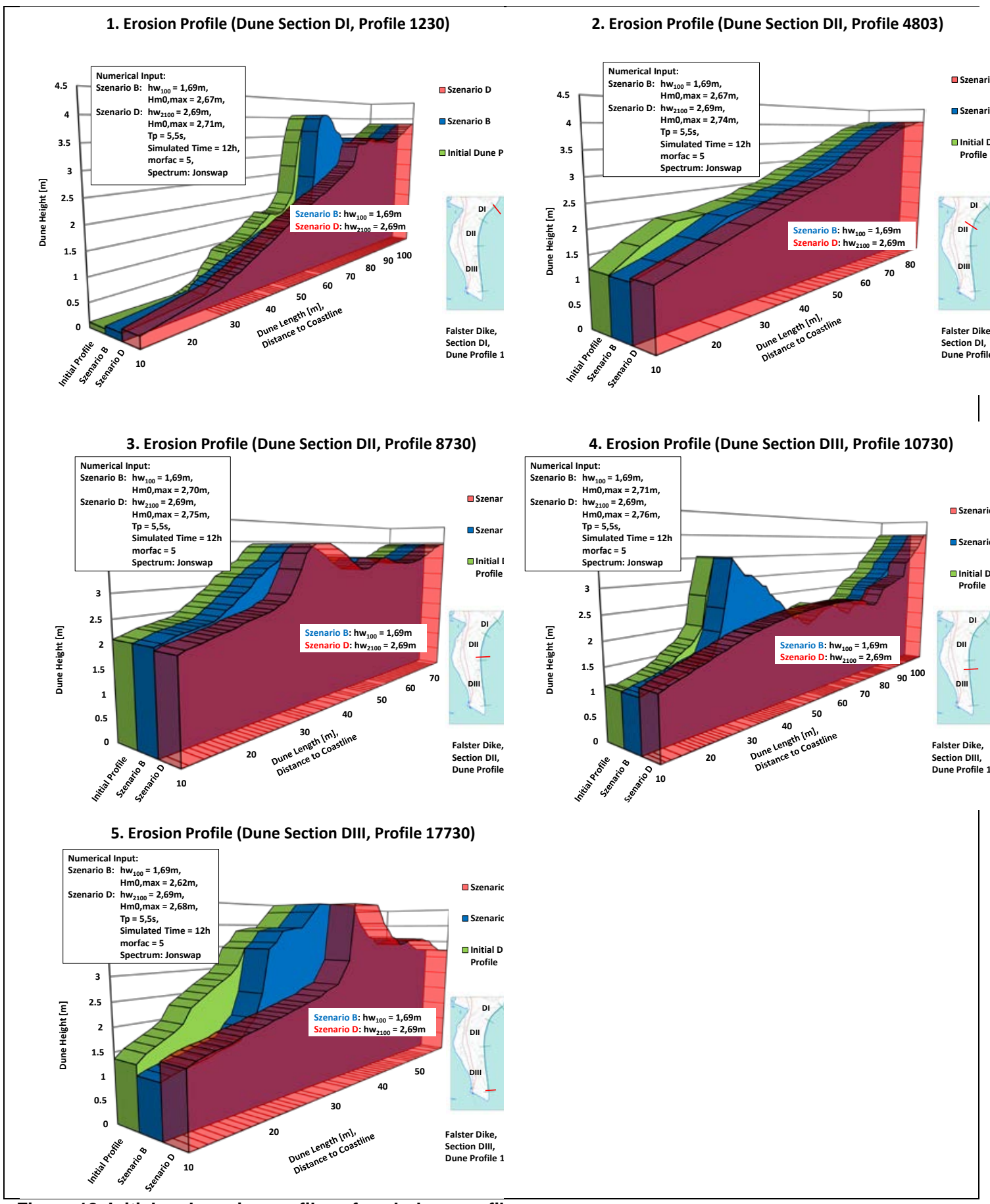

Figure 12. Initial and erosion profiles of each dune profile 
A GIS analysis of high resolution topography was performed to compare the characteristics of the dune cross sections. The additional dune profiles in DII and DIII are quite unique because they either consist of an asphalt crossing (crossing no. 5 in Marielyst) through the dike-dune system (Figure 12, initial profile 2) or they represent the dune at the south end of Falster where the dike line is missing, (Figure 12, initial profile 5).

The wave parameters calculated by SWAN are used as hydraulic input parameters for the numerical XBeach simulations. Values between $\mathrm{H}_{\mathrm{m} 0}=2.67 \mathrm{~m}-2.75 \mathrm{~m}$ for the different cross sections located along the coastline were obtained. Water levels of $h_{w, 100}=1.69 \mathrm{~m}$ in scenario $B$ and $h_{w, 2100}=2.69 \mathrm{~m}$ in scenario D were estimated to analyse high and extreme storm surge events so that the safety of the combination of dike and dunes could be assessed. Scenario D was then used to determine the maximum erosion profile for further combination of the dune and the dike. The wave period $T_{p}=5.5 \mathrm{~s}$ and the simulated storm duration $\mathrm{t}=12 \mathrm{~h}$ remain constant for all simulation runs.

A sieve sample analysis of dune sand material next to crossing no. 5 in Marielyst yields a mean grain diameter $d_{50}=0.2 \mathrm{~mm}$ with $d_{90}=0.3 \mathrm{~mm}$. The uniformity of the dune sand was determined to $\mathrm{C}_{\mathrm{u}}=1.8$. These characteristics were taken into account as an input for XBeach.

\section{Dune Erosion}

The initial profile of the dunes (green) and the erosion profiles for scenario B (blue) and D (red) are shown in Figure 12, respectively where the y-axis represents the dune height and the $\mathrm{x}$ - axis represents the distance to the coastline.

It can be seen from Figure 12, that only small erosion volumes at the dune toe were observed for each cross section profile for storm surge scenario B. This means that the dunes are not eroded under these conditions and therefore do not lose their protective functions.

In Scenario D, the erosion volume increases significantly as compared to scenario B for each cross section profile (Figure 12). In case of the 4th erosion profile (Figure 12, erosion profile 4) the dune is completely eroded and a berm like structure has been generated. Once the dune is fully eroded only the dike line behind in combination with the created berm structure protects the hinterland from flooding. This is considered the worst case scenario and used for further calculations.

Regarding the two additional cross sections, the crossing in Marielyst (Figure 12, erosion profile 2) and the cross section at the south end without the dike behind (Figure 12, erosion profile 5), no significant changes with respect to the erosion volumes are observed. In the first case, hardly any erosion is visible which is due to the shallow dune front in this area. Therefore, wave run-up is most likely the critical factor. In the latter case, approximately half of the dune cross section is eroded, leaving the other half of the dune to protect the hinterland from flooding.

Wave Run-up and Overwash

Wave run-up is calculated by an internal function of the XBeach program (Roelvink et al., 2010). For each time step, the last wet point on the beach is provided and interpreted as the actual wave runup. The maximum run-up and the corresponding time can be found by analyzing the whole time series. For each cross section this wave run-up is calculated for scenario B (blue) and scenario D (red). For further analysis, only the worst case scenario (Figure 12, erosion profile 4) from the erosion analysis and the two additional profiles in Marielyst (Figure 12, erosion profile 2) and the dune profile without dike south of the Falster Dike (Figure 12, erosion profile 5) were investigated. Wave run-up, overwash and dune breach for the worst case scenario D (Figure 12, erosion profile 4) are shown in Figure 13 for dune section DIII.

In Figure 13, wave run-up can be observed in front of the dune, followed by erosion and overwash of the dune. After a storm surge duration of 4.9 hours the dune breaches and wave run-up occurs for the next 7.1 hours on the dike, resulting in erosion of the seaward dike slope. The maximum wave run-up is about $3.1 \mathrm{~m}$ which is still approximately $1.0 \mathrm{~m}$ lower than the dike crest. After the storm, when the water level is lowered again to mean water level, the dune is fully eroded and the eroded dune material is displaced and formed to a berm structure in front of the dike.

Wave run-up for the two additional profiles in Marielyst (Figure 12, erosion profile 2) and the dune without dike (Figure 12, erosion profile 5) for scenario D are given in Figure 14. In the case of Marielyst a maximum wave run-up of $3.2 \mathrm{~m}$ is observed, approximately $1.0 \mathrm{~m}$ lower than the dike crest. This is of major importance for the crossing, since there is no dune protection in front and a relatively low slope. In the case of the dune at the Falster south end with no dike behind, a maximum wave 
run-up of $3.2 \mathrm{~m}$ is observed, which is approximately $1.8 \mathrm{~m}$ lower than the dune top. In both cases only wave run-up and no overwash is observed, so that there will be no flooding of the hinterland.

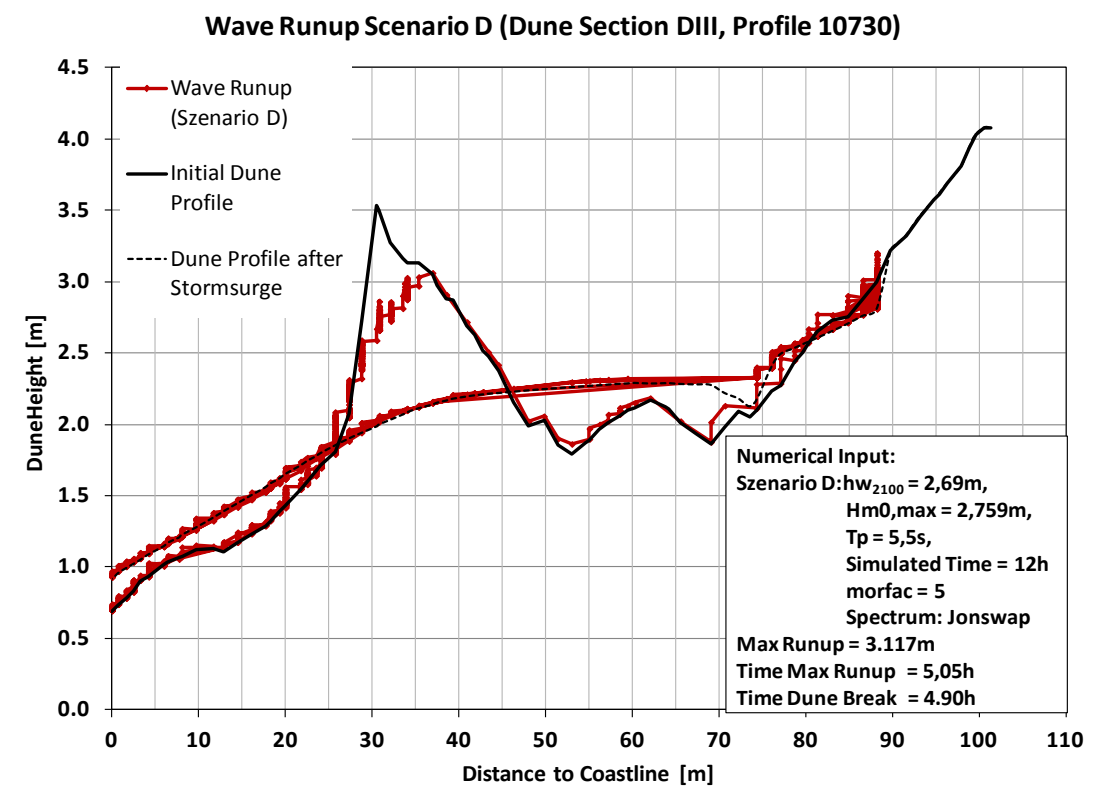

Figure 13. Wave run-up and dune breach, $4^{\text {th }}$ erosion profile dune section DIII and scenario D
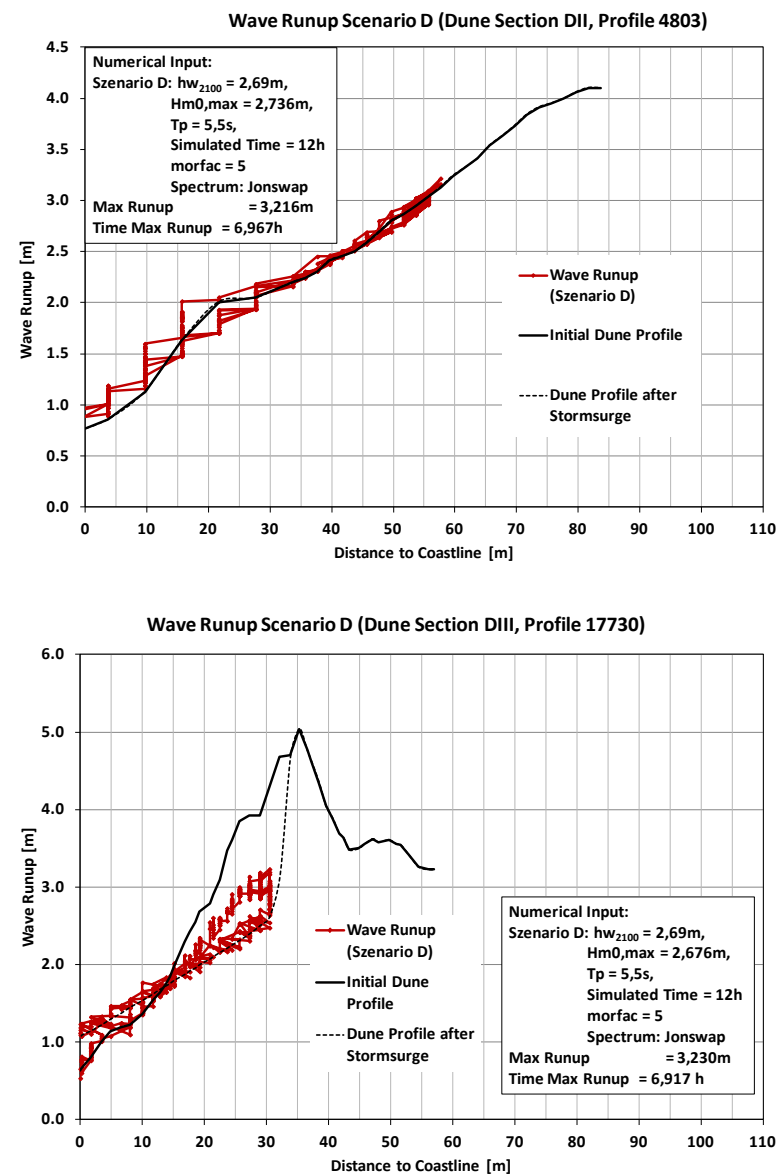

Figure 14. Wave run-up at crossing Marielyst (left) and Falster south end (without dike behind) (right) 


\section{Dune Crossing}

As an example of a dune crossing, the biggest crossing, no. 5 in Marielyst, was chosen. The XBeach model was used to determine the wave run-up and erosion for this special geometry. The simulation was run two times for the same profile, first with a non erodible asphalt layer and second, with erodible sand material as bottom layer. In the first case no erosion occurred in the area which was covered by asphalt but at the seaward end of the asphalt layer and in the latter case some small erosion over a longer distance was observed.

Considering the dune cross section at the South end of the Falster Dike, without a dike structure behind and storm surge scenario D, it was observed that approximately $50 \%$ of the dune was eroded. Only wave run-up and erosion but no overwash was observed.

\section{Deterministic Analysis of Wave Loading}

The following three cases

- $\quad$ dunes without considering the dike (Figure 7b),

- dike without considering the dunes (Figure 7c),

- $\quad$ dike with a berm (combination of dike and dunes) (Figure 7d).

will be analysed with respect to wave run-up and mean wave overtopping rates in this section. All four scenarios for water levels are considered for each of these three cases and will be discussed in the subsections below.

\section{Assessment of Dike without Considering Dunes}

In this section, the dunes in front of the dike were neglected for the calculation of wave run-up and wave overtopping rates. For each section, the dike slope on the seaward side is determined using the cross profile from the topography in this section. Calculations were performed according to the EurOtop Manual (EurOtop, 2007). The wave overtopping rates for scenario A, B, C and D are shown in Figure 15 together with the two admissible wave overtopping rates of $0.5 \mathrm{l} /(\mathrm{s} \cdot \mathrm{m})$ and $2.0 \mathrm{l} /(\mathrm{s} \cdot \mathrm{m})$.

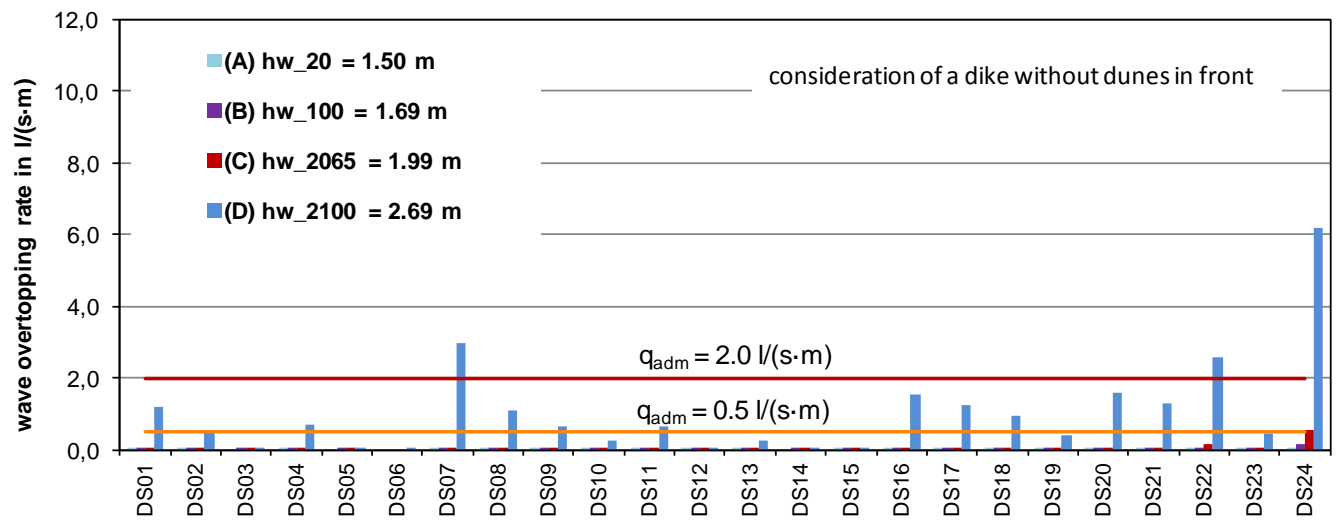

Figure 15. Calculated maximum wave overtopping rates for each dike section and water level scenario $\left[q_{\max }=\right.$ $6.1 \mathrm{l} /(\mathrm{s} \cdot \mathrm{m})]$

Dike sections DS07, DS22, and DS24 exceeded the admissible wave overtopping rate of $2.0 \mathrm{l} /(\mathrm{s} \cdot \mathrm{m})$ for the worst case scenario D. Mainly influenced by the outer dike slope, these dike sections are the most critical sections. For all other scenarios the maximum wave overtopping rate amounted to $0.6 \mathrm{l} /(\mathrm{s} \cdot \mathrm{m})$ and were therefore always below $2.0 \mathrm{l} /(\mathrm{s} \cdot \mathrm{m})$.

\section{Assessment of Dike with Berm}

To consider a combination of dike and dune, the dune erosion model was applied to three dune sections (DI, DII, DIII). In case of erosion profile 4, dune section III, (Figure 12, erosion profile 4) the dune is completely eroded and a berm like structure has been generated. Therefore, the wave overtopping calculations were revised using a berm in front of the dike for all three dune sections. Figure 16 shows an example of determining the berm and dike parameters at dune section DI. 


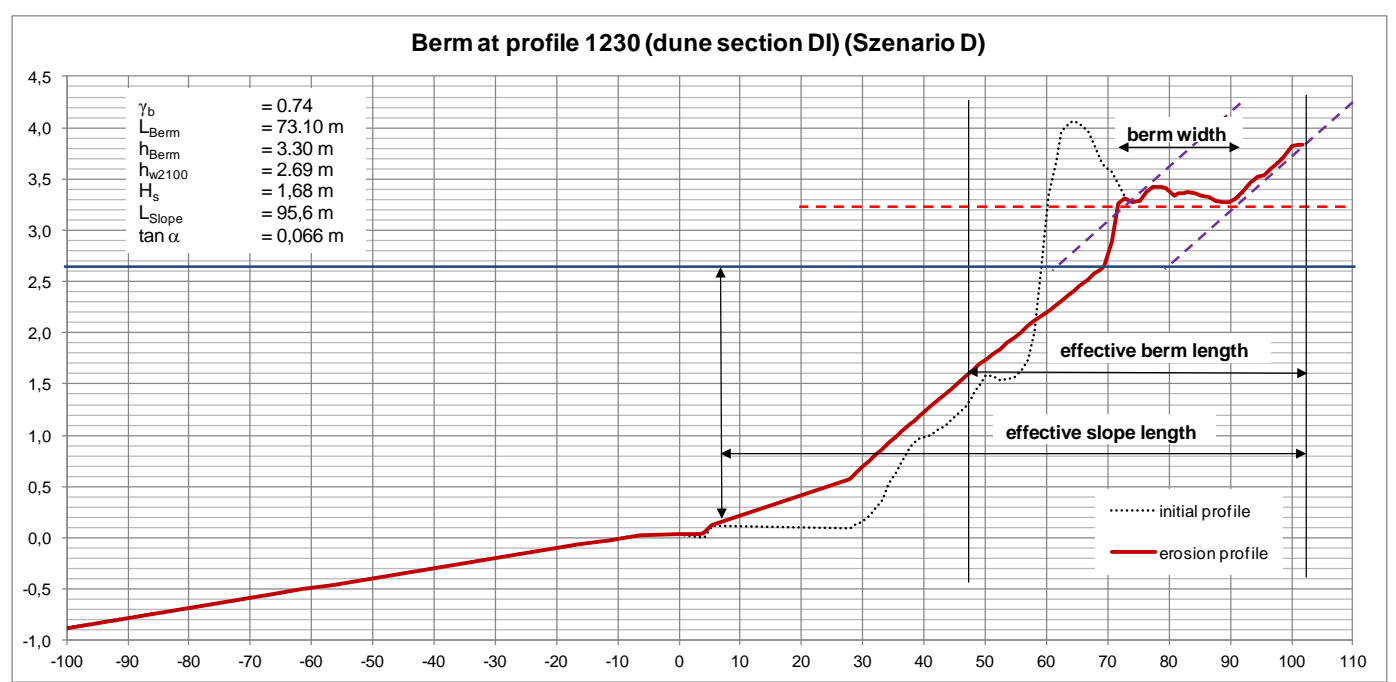

Figure 16. Determination of effective berm length and berm width (dune section DI) (Scenario D)

The consideration of different berm profiles for scenario A, B, C and D for each dune section resulted in different berm factors $\gamma_{b}$ for the calculation of wave run-up and overtopping. Furthermore, it should be noted that the water level was kept constant for all calculations performed here. This is considered a very conservative approach since the water level will change over time (during a storm surge) so that the calculated results for wave run-up and overtopping will only be valid during the maximum peak water level and are considered to be significantly lower during all other times.

From North to South of the Falster Dike the berm width is increasing by a larger distance between dune and dike (from $19.3 \mathrm{~m}$ to $37.3 \mathrm{~m}$ ). In addition, the berm height varies from $2.3 \mathrm{~m}$ to $3.4 \mathrm{~m}$. Considering these dimensions berm factors were determined and the wave overtopping rates were calculated for each scenario. In Figure 17 the maximum wave overtopping rates (considering completely eroded dunes) are shown.

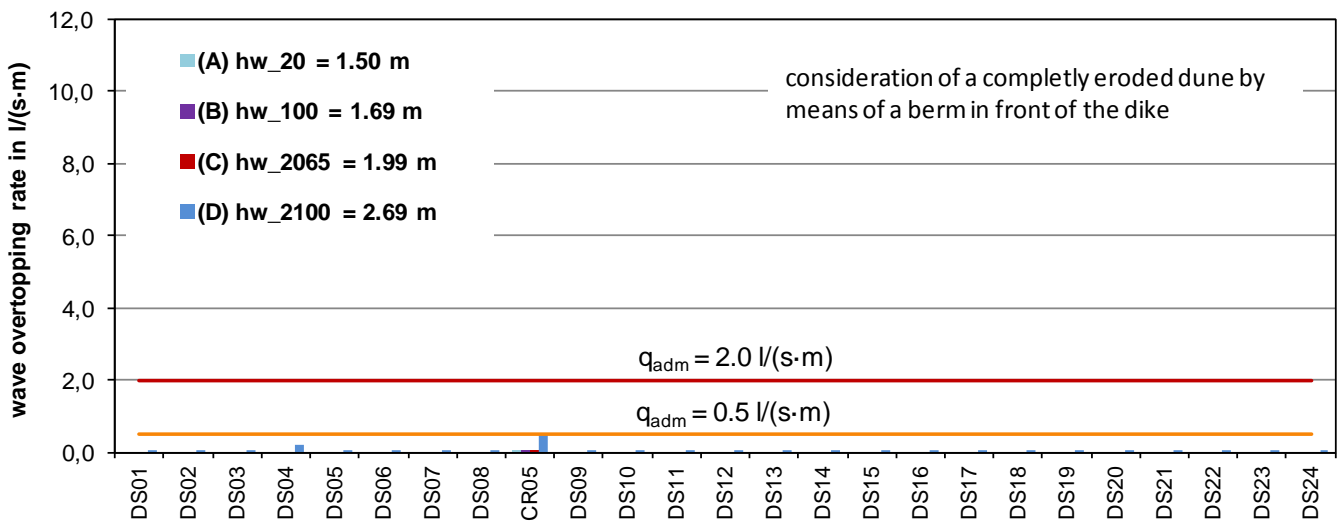

Figure 17. Calculated maximum wave overtopping rates for each dike section and water level scenario with consideration of completely eroded dunes $\left[q_{\max }=0.5 \mathrm{I} /(\mathrm{s} \cdot \mathrm{m})\right]$

For the case of a completely eroded dune, a berm will stay in front of the dike. This case yields a much lower wave run-up and mean wave overtopping rate. A larger distance between dune and dike also decreases the wave run-up and wave overtopping rate because of a larger berm width and a shallower dike slope. Dune section DIII has a lower berm height which leads to a higher potential wave run-up and wave overtopping rate as compared to dune sections DI and DII.

Through the combination of dikes and dunes, it could be concluded, that there is a considerable extra safety of the dike by the dunes in front. Even if the dunes are entirely eroded, the berm in front of the dike reduces the wave overtopping rate. At the crossing no. 5 in Marielyst, the highest wave overtopping rate amounted to $\mathrm{q}_{\max }=0.5 \mathrm{l} /(\mathrm{s} \cdot \mathrm{m})$. Hence, no wave overtopping rate exceeded the admissible values. 


\section{Probabilistic Analysis of Wave Loading}

A probabilistic approach was applied with using the software tool Palisade @Risk by means of a Monte-Carlo-Simulation. In a first approach, the dunes were neglected for the probabilistic calculation (cf. Figure 7c). A maximum failure probability $\mathrm{P}_{\mathrm{f}}=0.43$ results for dike section DS18 when only wave overtopping is considered as failure mode and when applying a scenario with a water level of $\mathrm{h}_{\mathrm{w} 100}=2.28 \mathrm{~m}$ (Kaste, 2011). Furthermore, relatively high failure probabilities due to wave overtopping were determined for DS19, DS20, DS22 and DS24.

In the next step, the probabilistic approach was applied to the combination of dike and dunes (cf. Figure 7d) taking into account the failure mechanisms 'wave overtopping', 'overflow' and 'erosion of outer dike slope'. The berm factors $\gamma \mathrm{b}$ for each dune section related to the dike sections were taken into account for scenario D.

The case of a dike with completely eroded dunes is applied for the probabilistic analysis. Therefore, there are changes in the geometry of the dike as compared to previous probability calculations. The results of probability calculations for all dike sections employing the berm factors from the fully eroded dunes were all determined as $\mathrm{P}_{\mathrm{f}}=0.0$ which means that the failure probabilities are smaller than $\mathrm{P}_{\mathrm{f}}=10^{-10}$. These probability calculations include additional failure modes than discussed before but also the previously considered ones ('wave overtopping', 'overflow' and 'erosion of the outer dike slope'). A critical overtopping rate was defined as $0.5 \mathrm{l} /(\mathrm{s} \cdot \mathrm{m})$. The results suggested that the Falster Dike system can be regarded safe under current and future water level scenarios as long as there is a full inspection and maintenance programme of the protection system carried out and both the dike and the dunes are kept in their current conditions.

\section{CONCLUDING REMARKS}

The reliability of Falster Dike as a coastal defence system was assessed, which includes the probability of failure of the most critical dike and dune sections. The objective is to determine suggestions of possible counter-measures based on the results of the safety assessment. The desk study comprised three distinct phases: (i) collation and analysis of data, including generation of missing data, (ii) preliminary analysis of hydraulic boundary conditions and wave loading (run-up and overtopping), and (iii) reliability analysis and counter-measures.

The results of this study suggested that the wave overtopping almost never exceeded the admissible wave overtopping rate $\left(\mathrm{q}_{\mathrm{adm} 1}=0.5 \mathrm{l} /(\mathrm{s} \cdot \mathrm{m})\right)$. Under current conditions the safety of the coastal protection system is fully sufficient. In the context of future conditions with a sea level rise in 2090 to 2100, wave overtopping rates exceeding the admissible value were predicted assuming that no dunes are present in front of the dikes. However, the dunes in front of the dike are there as an extra safety and no wave overtopping can occur.

The following conclusions can be drawn:

- $\quad$ The methodological approach comprised different steps in assessing the safety by considering only dike sections, only the dunes, and eventually a combined and simplified system.

- Assuming only the dike as flood protection, no significant wave overtopping for scenarios A, $\mathrm{B}$, and $\mathrm{C}$ was determined while scenario $\mathrm{D}$ has led to wave overtopping rates up to $6.2 \mathrm{l} /(\mathrm{s} \cdot \mathrm{m})$. However, since the dunes are present in front of the dike, wave overtopping in scenario $\mathrm{D}$ will not occur. This again shows the importance of having a dune in front of the dike.

- The combination of dunes and dikes adds a significant extra safety so that the safety of the Falster Dike is regarded sufficient and there is no immediate need for any countermeasures to be installed. However, inspection and maintenance of the dunes and the dike is essential and needs to be performed.

\section{ACKNOWLEDGEMENTS}

The 'Falster Dike' project was funded by the Falster Dike Board the support of which is gratefully acknowledged. The collaboration with the Danish Coastal Authority (DCA, Thorsten Piontkowitz and Holger Toxvig) is also very much appreciated and has proved to be very successful for the final results of the project. 
REFERENCES

DCA 2007: Hojvandsstatistikker - Extreme sea level statistics for Denmark. Danish Coastal Authority, Lemvig, Denmark.

DHI 2006: Vandstandsstatistik for Koege Havn. DHI Institu for Vand og Miljo, Horsholm, 16 p.

DMI 2011: Wind data of Gedser Havn (01.01.06-31.08.11) and Gedser Odden (01.01.94-31.08.11), Danmarks Meteorologiske Institut (DMI).

EAK 2002: Empfehlungen für Küstenschutzwerke. Die Küste. Archiv für Forschung und Technik an der Nord- und Ostsee, Heft 65, Boyens \& Co., 589 S.

EurOtop 2007: European Overtopping Manual. Pullen, T.; Allsop, N.W.H.; Bruce, T.; Kortenhaus, A.; Schüttrumpf, H.; Van der Meer, J.W.; Kuratorium für Forschung im Küsteningenieurwesen: Die Küste, Heft 73, www.overtopping-manual.com.

FDB 2011a: Data of echo sounder measurements at east coast of Falster Island, Danish Coastal Authority, Lemvig, Denmark. unpublished.

FDB 2011b: Topography data of coastline of Southeast Falster, Falster Dike Board (FDB).

Kaste, D. 2011: Safety Assessment of the Coastal Protection System at Falster, Denmark. Diplomarbeit am Leichtweiß-Institut für Wasserbau, Fachbereich Bauingenieurwesen, Technische Universität Braunschweig, Braunschweig, Germany, 49 p., 10 appendices.

Rasmussen, F.F., K. Dreijer and G. Jørgensen. 1997: Det falsterkse dige. Nykøbing Falster, 96 p.

Roelvink, D., A. Reniers, A. van Dongeren, J. van Thiel de Vries, J. Lescinski and R. McCall. 2010: XBeach Model Description and Manual. Unesco-IHE Institute for Water Education, Deltares and Delft University of Technology, 1002266, Delft, 106 p.

Seifert, T., F. Tauber and B. Kayser. 2001: A high resolution spherical grid topography of the Baltic Sea - 2nd edition. Baltic Sea Science Congress, 25-29. November 2001, Stockholm Poster \#147.

SPM 1984: Shore protection manual, vol. I, Chapters 1 through 5. Vicksburg, Mississippi, USA, 800 p.

Streicher, M. 2012: Numerical Simulation of Coastal Dune Erosion due to Storm Surges Using XBeach. Entwurf am Leichtweiß-Institut für Wasserbau, Fachbereich Bauingenieurwesen, Technische Universität Braunschweig, Braunschweig, 79 p.

SWAN 2006: SWAN Scientific and technical documentation. Delft University of Technology, Delft, Netherlands, $126 \mathrm{p}$.

Wahl, T. 2007: Ermittlung von Seegangsbelastungen im Küstennahbereich mit dem numerischen Seegangsmodell SWAN. Diplomarbeit am Forschungsinstitut Wasser und Umwelt, Abt. Wasserbau \& Hydromechanik der Universität Siegen, Siegen, 161 p. 